\title{
THE RELATIONSHIP BETWEEN HOTELS' ENVIRONMENTAL PERFORMANCE AND SOCIAL RESPONSIBILITY: CASE STUDY ON ITALIAN HOTELS FROM VENETO REGION
}

\author{
Mirela Stefanica ${ }^{79}$ \\ Christiana Brigitte Sandu ${ }^{80}$
}

https://doi.org/10.31410/itema.2018.202

\begin{abstract}
Hotels' environmental protection activities have impact on the sustainable development of tourism industry and support sustainable ecologic systems. The aim of this paper is to explain the relationship between hotels' environmental performance, achieved through the implementation of good managerial eco-practices, and the social responsibility. This study was conducted on a sample of 43 hotel establishments with three or more stars, located in the Veneto region of Italy. The managerial eco-practices have been assessed trough the following dimensions: eco-friendly purchases and suppliers, energetic efficiency monitoring, waste management, recycling, water management and staff ecological formation. For hypotheses testing the Partial Least Squares analysis was performed using the Smart PLS version 3.0 software. Research results confirm that good eco-practices of hotel managers lead to environmental performance. Moreover, the results also suggest that hotel managers from Veneto region are involved in programs and projects with a role in enhancing environmental issues, thus demonstrating social responsibility. The paper highlights the importance of hotels' ecological behavior, emphasizing its role in achieving environmental performance. The results have managerial implications that should encourage hotel managers to adopt eco-practices in order to achieve environmental performance and increase social responsibility.
\end{abstract}

Keywords: good managerial eco-practices, recycling, waste and water management, ecofriendly purchases, PLS-SEM

\section{INTRODUCTION}

$\mathrm{T}$ The environmental performance, the measures implemented to achieve it, the environmental strategies adopted in the tourism industry, and the factors and tools underpinning have been important issues in tourism research [1]- [4].

Theoretical and practical approaches in the field of tourism have placed great emphasis on economic and social performance and have been less concerned about the environment. Recent studies have shown that economic performance was monitored, for example, by $66 \%$ of the respondents, while the environmental and social performance were monitored by only $42 \%$ and $28 \%$ of the respondents, respectively [5].

The concept of environmental performance refers to measurable results of the environmental management system, linked to organizational monitoring of the environmental issues, based on

\footnotetext{
${ }^{79}$ Faculty of Economics and Business Administration, “Alexandru Ioan Cuza” University of Iasi, 22 Carol I Avenue, Building B, Room B-527, code 700505, Iasi, Romania

${ }^{80}$ Faculty of Economics and Business Administration, “Alexandru Ioan Cuza” University of Iasi, 22 Carol I Avenue, Building B, Room B-315, code 700505, Iasi, Romania
} 
its policy, general objectives and specific environmental objectives [6]. In tourism, the achievement of environmental performance does not only comply with minimum environmental standards but also refers to the adoption of best practices, accreditation schemes, codes of ethics, and environmental certification [7], [8]. Moreover, every manager is concerned with maximizing the positive impact and minimizing the negative impact of the organization on society, and consequently with increasing the organization's social responsibility [9]. It can be noticed an evolutionary process at firms' level with regard to the integration of environmental issues into complex strategic plans. It has been highlighted that the inclusion of environmental issues among the main concerns of large-scale general planning also entails increased social responsibility [10].

Therefore, our study aims to assess the implementation of good managerial practices in hotels and consequently to study the relationship between achieving environmental performance and social responsibility. Our goal is to highlight that hotel managers interested in reaching environmental performance are more involved in programs and projects with a role in improving environmental issues and they are more socially responsible.

\section{LITERATURE REVIEW}

Many studies have emphasized the fact that hotel industry is a high-energy intensive and polluting sector [11]-[13]. It has been observed that a hotel produces between 160 and $200 \mathrm{~kg}$ of carbon dioxide $\left(\mathrm{CO}_{2}\right)$ per square meter in order to generate electricity, heating or cooling, in dependence to the type of fuel used. In the case of European hotels, yearly energy consumption is of 39 twh (terawatts per hour) and the emissions are responsible for approximately 13.6 megatons of $\mathrm{CO}_{2}$. Additionally, tourists consume between 170 and 440 liters of water per day and each tourist produces about one $\mathrm{kg}$ of daily waste, of which no more than $60 \%$ is recyclable [11].

It has been argued that many hotel operators have little interest in undertaking actions such as reducing waste, implementing an efficient waste management or recycling, considering that such activities are highly costly and time-consuming [4]. More recently, based on a cost-benefit analysis of the impact of the hotel industry on waste management, it has been underlined that providing a solid waste management in hotels and implementing specific practices for waste prevention / minimization at source are highly important [13]. Considering that solid waste generation and disposal is one of the most negative effects on the environment, some studies have developed good practice models that policymakers should be encouraged to implement in their hotels [3], [4].

A study on recycling gray water and reducing water consumption in hotels suggests implementing a water management system through 4Rs approach: Innovative Reducing, Innovative Reusing, Innovative Reaching and Innovative Recycling [14]. By implementing water management system, hotels have obtained commercial benefit irrespective to hotels' size or different managerial capacities. Other authors have found that implementing environmental measures leads to customer benefits, energy efficiency, efficient water use, thus influencing recycling policy and green living characteristics of hotels [15].

Recent studies have identified six key factors in achieving environmental performance, namely: environmental education and staff training support for the host community, support for preservation projects, compliance with environmental regulations, waste management and volunteer programs [1]. It has been noticed that higher rated or larger hotels have improved 
their environmental performance, while affiliation to hotel chains has not led to higher performance. The effective use of lighting and the elimination of diesel use are the most common strategies in Mexican hotels in order to improve environmental performance. Nevertheless, hotels have begun to become involved in preserving and recycling programs as a means of reducing energy costs and solid waste [16].

The analysis of voluntary environmental instruments used to achieve environmental performance (codes of conduct, environmental best practices, eco-labels, EMS - environmental management systems and environmental performance indicators) has allowed identifying formal certification systems, such as eco-labels and EMS as the most effective tools in achieving environmental performance [2].

Recent studies on the relationship between hotels' environment initiatives and financial performance have highlighted that companies' financial performance can have influence on environmental performance, as firms with good financial performance are better able to allocate more resources to support environment initiatives [17]. However, other studies have come to the conclusion that environmental practices have a direct and significant impact on the competitiveness of hotels and their financial results [18], [19]. Thus, the use of environmental management systems is associated with cost-saving innovations, while innovations in water and energy saving, wastewater treatment, noise reduction, sound insulation have contributed to increasing hotel's quality and competitiveness [20].

It is worth noting that obtaining environmental performance means savings, competitive advantage, employees' loyalty, customers' fidelity, compliance with regulations, risk management and social responsibility [21]. A recent study highlighted that hotels communicate fewer pro-environment practices than they actually achieve, and there has been shown that only $30 \%$ of these practices are made public [22]. Nevertheless, there is still a great gap between attitude and action in the tourism industry.

\section{RESEARCH HYPOTHESES. CONCEPTUAL MODEL}

The aim of this study is to analyze the relationship that exists between good eco-managerial practices, environmental performance and social responsibility. Consequently, we have developed the following conceptual model presented in Figure 1.

Figure 1: Conceptual model

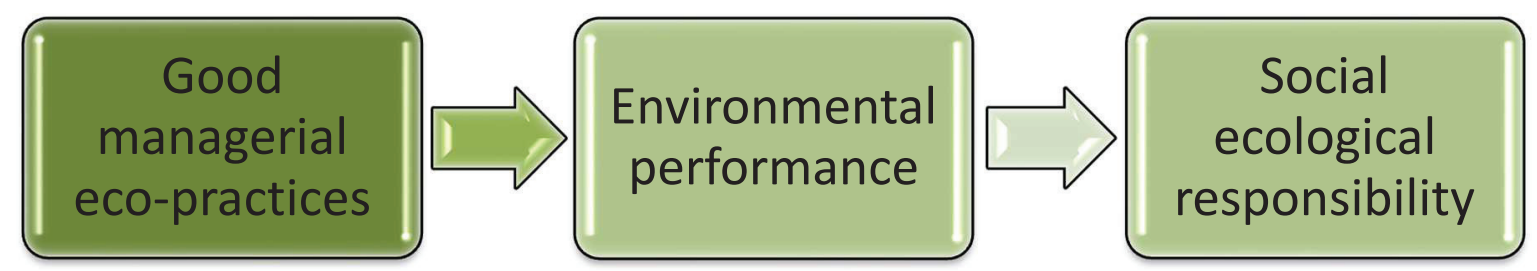

Eco-managerial practices relate to efficient waste management, energy consumption reduction, recycling, eco-friendly purchasing, staff training - all of which play an important role in achieving environmental performance that can influence increase of social responsibility. We have advanced two hypotheses:

H1: There is a direct and positive relationship between good managerial eco-practices and the hotel's environmental performance 
H2: There is a direct and positive relationship between the environmental performance and the ecological social responsibility of the hotel

\section{RESEARCH METHODOLOGY}

For this study, data have been collected through a survey. The benefit of this approach is that it provides more flexibility and data gathering is faster than other methods.

The questionnaire was designed to assess the eco-managerial practices and the social ecological responsibility behavior of hotels' managers. All survey questions utilized a five-point Likert scale that offered a range of answer options from 1 - "strongly disagree" to 5 - "strongly agree". The questionnaire has been pre-tested within a pilot survey on a small convenience sample in order to verify the appropriateness of questions. After the errors have been solved the actual survey was executed.

The sample comprised 43 hotels from the Veneto Region of Italy. The Veneto Region is located in north-eastern Italy and comprises seven provinces, namely: Belluno, Padova, Rovigo, Treviso, Venice, Verona, and Vicenza. The hotels were selected based on accessibility.

The sample structure according to a set of characteristics such as property type, hotel classification and hotel size (upon the number of employees) is presented in Table1.

Table 1: Sample structure

\begin{tabular}{|c|c|}
\hline Hotel's characteristics & $N(\%)$ \\
\hline \multicolumn{2}{|l|}{ Type of property } \\
\hline Independent hotel & $31(72.1 \%)$ \\
\hline Chain hotel & $12(27.9 \%)$ \\
\hline \multicolumn{2}{|l|}{ Classification } \\
\hline 3 stars & $14(32.6 \%)$ \\
\hline 4 and 5 stars & $29(67.4 \%)$ \\
\hline \multicolumn{2}{|l|}{ Size } \\
\hline Small and Medium & $29(67.4 \%)$ \\
\hline Large & $14(32.6 \%)$ \\
\hline
\end{tabular}

For testing the relationship between the constructs, structural equation modeling based on partial least squares method was used. We have applied partial least square analysis (PLS) using SmartPLS (v. 3.2.7) software [23]. The PLS handles two models: the outer model (the measurement model) relating the manifest (observable) variables to their own latent variables; and the inner model (the structural model) relating some latent variables to other latent variables. The measurement model is tested by the reliability and validity analyses while the structural model is tested by path coefficients between constructs and the model.

\section{RESEARCH RESULTS}

Convergent reliability and validity indicators (Cronbach's alpha, AVE - average variance extracted, CR - composite reliability) measure the degree to which the items quantifying the same concept are in consistency [24]. We can conclude that the measurement model is valid and reliable when the alpha values are above 0.6; the AVE values are greater than 0.5 ; the CR values for all constructs are above 0.7 . 
The results presented in Table 2 on the measurement model indicate an adequate level of convergent reliability and validity. The list of constructs and measuring items is presented in the Appendix.

Table 2: Convergent reliability and validity

\begin{tabular}{l|cccc}
\hline Construct & $\begin{array}{r}\text { Cronbach's } \\
\text { Alpha }\end{array}$ & rho_A & $\begin{array}{r}\text { Composite } \\
\text { Reliability } \\
\text { (CR) }\end{array}$ & $\begin{array}{r}\text { Average Variance } \\
\text { Extracted (AVE) }\end{array}$ \\
\hline Staff ecological training & 0.839 & 0.860 & 0.905 & 0.763 \\
Energy efficiency monitoring & 0.841 & 0.862 & 0.883 & 0.563 \\
Waste management & 0.761 & 0.774 & 0.862 & 0.676 \\
Water management & 0.517 & 0.549 & 0.749 & 0.502 \\
Recycling & 0.832 & 0.180 & 0.764 & 0.549 \\
Environment performance & 0.858 & 0.892 & 0.875 & 0.256 \\
Ecological products & 0.817 & 0.818 & 0.879 & 0.646 \\
Eco purchases and suppliers & 0.730 & 0.775 & 0.829 & 0.554 \\
Eco friendly & 0.880 & 0.897 & 0.905 & 0.521 \\
Social & 0.661 & 0.816 & 0.774 & 0.385 \\
responsibility & & & & \\
\hline
\end{tabular}

Furthermore, the hypothesized relationships in the structural model were tested. Bootstrapping procedure was used to verify the significance levels of path coefficients.

Table 3 shows that path coefficients are significant between constructs in the model. These results show a strong support for the two hypotheses of this study. The path coefficient "Energy efficiency monitoring $\rightarrow$ Environment performance" with 0.556 followed by the path coefficient "Eco friendly $\rightarrow>$ Environment performance" with 0.470 show that eco managerial practices (except for recycling) have a positive effect on environment performance. Thus, the first hypothesis $\left(\mathrm{H}_{1}\right)$ is supported by the data. Similarly, the results show a strong support for the second hypothesis $\left(\mathrm{H}_{2}\right)$. There is a positive and significant effect of environment performance on social ecological responsibility.

Table 3: Testing of significance of path coefficients

\begin{tabular}{|l|c|c|}
\hline Relationships & $\begin{array}{r}\text { Path } \\
\text { coefficient }\end{array}$ & T Statistics \\
\hline Staff ecological training -> Energy efficiency monitoring & $0.767^{* * *}$ & 25.845 \\
\hline Staff ecological training -> Water Management & $0.395^{* * *}$ & 4.939 \\
\hline Ecological products -> Eco friendly & $0.493^{* * *}$ & 18.011 \\
\hline Eco purchases and suppliers -> Eco friendly & $0.436^{* * *}$ & 17.033 \\
\hline Technologies -> Eco friendly & $0.180^{* * *}$ & 10.707 \\
\hline $\begin{array}{l}\text { Energetic efficiency monitoring -> Environment } \\
\text { performance }\end{array}$ & $0.556^{* * *}$ & 4.371 \\
\hline Waste management -> Environment performance & $0.190^{* *}$ & 3.160 \\
\hline Water management -> Environment performance & $0.156^{* * *}$ & 4.573 \\
\hline Recycling -> Environment performance & -0.012 & 0.838 \\
\hline Eco friendly -> Environment performance & $0.470^{* * *}$ & 3.788 \\
\hline $\begin{array}{l}\text { Environment performance -> Social ecological } \\
\text { responsibility }\end{array}$ & $0.559^{* * *}$ & 7.114 \\
\hline
\end{tabular}

Note: $* * * \mathrm{p}$ value $<0.001,{ }^{* *} \mathrm{p}$ value $<0.01, * \mathrm{p}$ value $<0.05$ 
The results in Table 3 and Figure 2 reveal that the path coefficients are above the recommended value of 0.1 [25]. Moreover, the combination of ecological managerial practices has the predictive ability for $99.2 \%$ of the Environmental performance. At the same time, Environmental performance has the ability to explain $31.3 \%$ of the Social eco responsibility.

Figure 2: Structural model

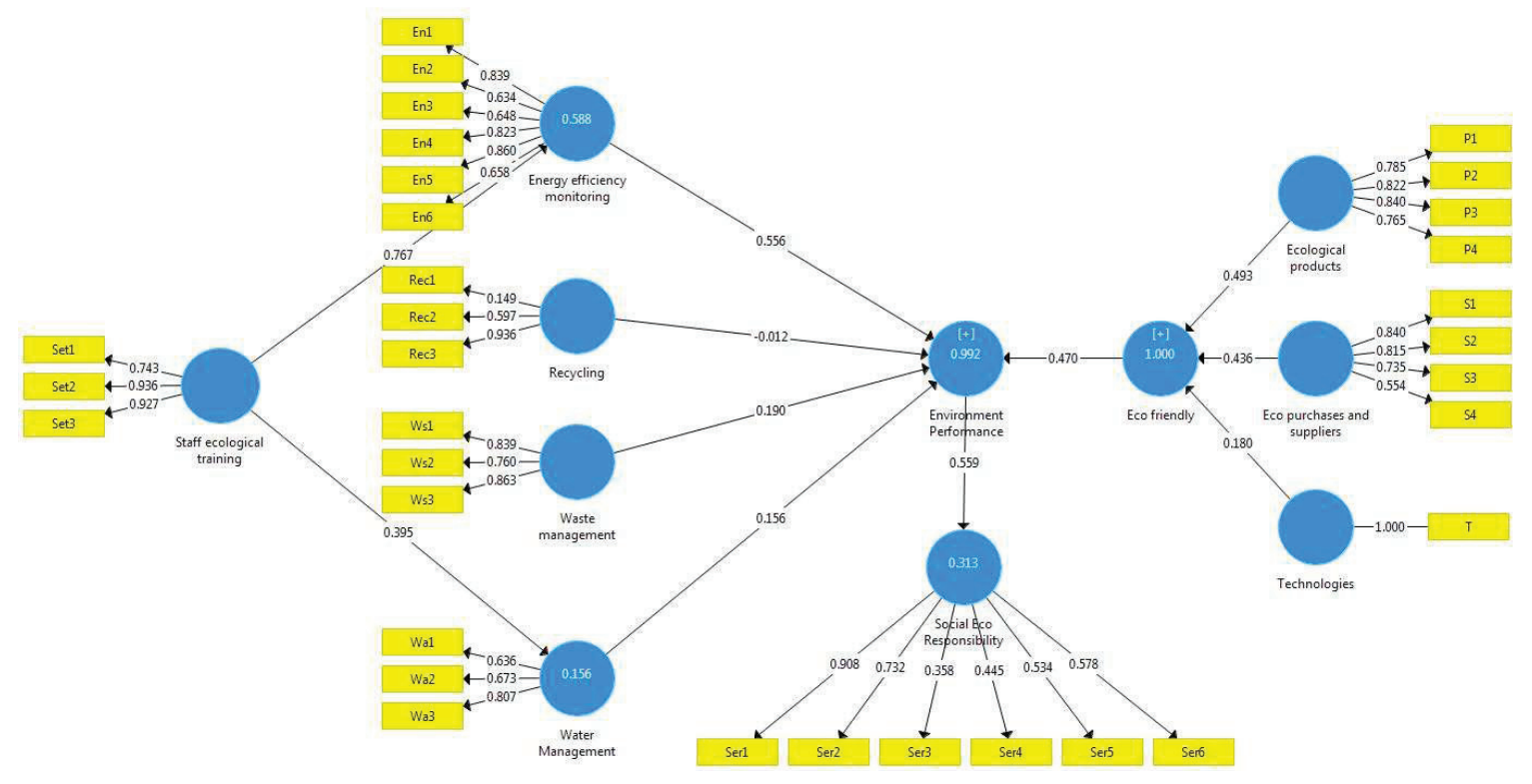

\section{CONCLUSIONS}

The result of the structural model showed that eco managerial practices of hotels' managers have a positive and significant impact on environment performance. Moreover, it was also observed that environment performance has effects on ecological social responsibility. Hence, the two hypotheses were accepted.

The limitations of this study refer to the specific region of Italy where the survey was conducted. A similar study may be conducted in other regions of Italy or in other countries.

We can conclude that hotel managers from Veneto region have an ecological behavior with impact on environmental performance. Furthermore, they are involved in programs and projects thus proving their role in a society.

\section{REFERENCES}

[1] Mensah, I., Blankson, E.J. (2013) Determinants of hotels' environmental performance: Evidence from the hotel industry in Accra, Ghana, Journal of Sustainable Tourism, 21:8, pp.1212-1231, DOI: 10.1080/09669582.2013.776058

[2] Ayuso, S. (2007) Comparing Voluntary Policy Instruments for Sustainable Tourism: The Experience of the Spanish Hotel Sector, Journal of Sustainable Tourism, 15:2, pp.144159, DOI: $10.2167 /$ jost617.0

[3] Radwan, H.R.I., Jones, E., Minoli, D. (2012) Solid waste management in small hotels: a comparison of green and non-green small hotels in Wales, Journal of Sustainable Tourism, 20:4, pp.533-550, DOI: 10.1080/09669582.2011.621539 
[4] Kasim, A. (2009) Managerial attitudes towards environmental management among small and medium hotels in Kuala Lumpur, Journal of Sustainable Tourism, 17:6, pp.709-725, DOI: $\underline{10.1080 / 09669580902928468}$

[5] Mihalič, T., Žabkar, V., Knežević, Cvelbar, L. (2012) A hotel sustainability business model: evidence from Slovenia, Journal of Sustainable Tourism, 20:5, pp.701719, DOI: $10.1080 / 09669582.2011 .632092$

[6] Hobincu, R.V. (2004) Politica de mediu şi crearea sistemelor de management de mediu, Perfect, Bucharest

[7] Honey, M., Rome, A. (2001) Protecting Paradise: Certification Programs for Sustainable Tourism and Ecotourism, Institute for Policy Studies, Washington.

[8] Popescu, C.R., Popescu, V.A., Popescu, G.N. (2014) The entrepreneur's role in the performance growth of the financial audit activity in Romania, Amfiteatru Economic 17(38), pp. 232-251

[9] Dumitriu, C. (2005), Management și marketing ecologic, Tehnopress, Iasi, pp.60-61

[10] Țigu, G., Călărețu, B. (2013) Performanţele Supply Chain Management în turism. Studiu de caz la S.C. Continental Hotels S.A., Amfiteatru Economic, XV (33), pp. 60-73

[11]Bohdanowicz, P. (2005) European Hoteliers Environmental Attitudes. Greening the Business, Cornell Hotel and Restaurant Administration Quarterly, Vol. 46, No. 2, pp. 188204, Available online: http://journals.sagepub.com/doi/pdf/10.1177/0010880404273891, (accessed on 12 July 2018).

[12]Ragab, A.M., Meis, S. (2016) Developing environmental performance measures for tourism using a Tourism Satellite Accounts approach: a pilot study of the accommodation industry in Egypt, Journal of Sustainable Tourism, 24:7, pp.10071023, DOI: $10.1080 / 09669582.2015 .1107078$

[13]Zorpas, A.A., Voukkali, I., Loizia, P. (2015) The impact of tourist sector in the waste management plans, Desalination and Water Treatment, 56:5, pp.11411149, DOI: 10.1080/19443994.2014.934721

[14]Kasim, A., Gursoy, D., Okumus, F., Wong, A. (2014) The importance of water management in hotels: a framework for sustainability through innovation, Journal of Sustainable Tourism, 22:7, pp.1090-1107, DOI: 10.1080/09669582.2013.873444

[15] Trang, H.L.T., Lee, J-S., Han, H. (2018) How do green attributes elicit pro-environmental behaviors in guests? The case of green hotels in Vietnam, Journal of Travel \& Tourism Marketing, DOI: 10.1080/10548408.2018.1486782

[16]Revilla, G., Dodd, T.H., Hoover, L.C. (2001) Environmental Tactics Used by Hotel Companies in Mexico, International Journal of Hospitality \& Tourism Administration, 1:34, pp.111-127, DOI: $10.1300 / J 149 v 01 n 03 \quad 07$

[17] Jackson, L.A., Singh, D., Parsa, H.G. (2015) Tourism firms' environmental rankings and financial performance: a multidimensional scaling approach, Journal of Sustainable Tourism, 23:10, pp.1426-1444, DOI: 10.1080/09669582.2015.1044534

[18]Bagur-Femenías, L., Martí, J., Rocafort, A. (2015) Impact of sustainable management policies on tourism companies' performance: the case of the metropolitan region of Madrid, Current Issues in Tourism, 18:4, pp.376390, DOI: $\underline{10.1080 / 13683500.2014 .932757}$

[19] López-Gamero, M.D., Pertusa-Ortega, E.M., Molina-Azorín, J.F., Tarí-Guilló, J.J., PereiraMoliner, J. (2016) Organizational antecedents and competitive consequences of environmental proactivity in the hotel industry, Journal of Sustainable Tourism, 24:7, pp.949-970, DOI: 10.1080/09669582.2015.1101124

[20]De Burgos-Jiménez, J., Cano-Guillén, C.J., Céspedes-Lorente, J.J. (2002) Planning and Control of Environmental Performance in Hotels, Journal of Sustainable Tourism, 10:3, pp.207-221, DOI: $\underline{10.1080 / 09669580208667163}$ 
[21] Graci, S., Dodds, R. (2008) Why Go Green? The Business Case for Environmental Commitment in the Canadian Hotel Industry, Anatolia, 19:2, pp.251270, DOI: $10.1080 / 13032917.2008 .9687072$

[22]Font, X., Elgammal, I., Lamond, I. (2017) Greenhushing: the deliberate under communicating of sustainability practices by tourism businesses, Journal of Sustainable Tourism, 25:7, pp.1007-1023, DOI: 10.1080/09669582.2016.1158829

[23]Ringle, C.M., Wende, S., Becker, J.-M. (2015) "SmartPLS 3." Boenningstedt: SmartPLS $\mathrm{GmbH}$, http://www.smartpls.com

[24] Hair Jr. J. F., Hult, G.T.M., Ringle. C., Sarsted, M. (2017) A primer on partial least squares structural equation modeling (PLS-SEM), Sage Publication

[25] Lohmoller, J.B. (1989) Latent variable path modeling with partial least squares, PhysicaVerlag, Heidelberg, Germany 
Appendix

\begin{tabular}{|c|c|}
\hline Construct & Measurement items \\
\hline \multicolumn{2}{|c|}{ Energy efficiency monitoring } \\
\hline En1 & Regular (monthly) monitoring of energy consumption \\
\hline En2 & Constant maintenance of the equipment \\
\hline En3 & High thermal insulation \\
\hline & Employees' instruction to disable power-consuming sources (electrical \\
\hline En4 & and home appliances, lights) when not in use \\
\hline En5 & Installation of an energy-efficient heating and AC system \\
\hline En6 & Heating control by a thermostat \\
\hline \multicolumn{2}{|c|}{ Waste management } \\
\hline Ws1 & Types and quantities of waste are monitored \\
\hline Ws2 & $\begin{array}{l}\text { There are identified ways to reduce waste and actions are taken } \\
\text { accordingly }\end{array}$ \\
\hline Ws3 & $\begin{array}{l}\text { There are systems to minimize waste and to reuse and recycle whenever } \\
\text { possible }\end{array}$ \\
\hline \multicolumn{2}{|l|}{ Recycling } \\
\hline Rec1 & Recycling paper and cardboard \\
\hline $\operatorname{Rec} 2$ & Plastic recycling \\
\hline Rec3 & Recycling glass \\
\hline
\end{tabular}

Water management

Wa1 $\quad \begin{aligned} & \text { Use of devices to reduce water flow in places of consumption (e.g. } \\ & \text { shower trays) }\end{aligned}$

Wa2 Use of ventilating devices for the aeration of water to the sink batteries

Wa3 Use of wastewater recycling systems (gray water)

\section{Staff ecological training}

\begin{tabular}{l|l} 
Set1 & The staff is regularly trained on environmental issues
\end{tabular}

Environmental policy or environmental policy statement is known by

Set2 all employees

Set3 $\quad$ commitment to continually improve environmental performance

\section{Ecological products}

\begin{tabular}{l|l} 
P1 & Use of biodegradable cleaning agents (detergents)
\end{tabular}

P2 Use of hygienic paper with eco-labeled or chemically untreated

P3 Use of biodegradable, recyclable or returnable packaging

P4 $\quad$ Use of natural shampoos and soaps

Eco purchases and suppliers

\begin{tabular}{l|l} 
S1 & Acquisition of organic products is a current policy of the hotel
\end{tabular}

S2 upon a supplier

In the contract with suppliers there are clauses requiring the use of as

S3 few packaging as possible

In the contract with suppliers there are clauses requiring the

S4

transportation of goods in a non-polluting way

Social ecological responsibility

\begin{tabular}{l|l} 
Ser1 & Supports reforestation projects
\end{tabular}

Ser2 Sponsors events to increase awareness and understanding of 


\begin{tabular}{l|l} 
& environmental issues \\
Ser3 & He is a member of an environmental protection association \\
Ser4 & Supports and sponsors environmental organizations \\
Ser5 & Makes donations to natural reserves \\
Ser6 & Participates in garbage collection programs
\end{tabular}

Table 4: Constructs and measuring items 